\title{
Hybrid Strategy Study : The Role of Entrepreneurial Orientation and Total Quality Management in MSMEs
}

\author{
Timotius. F.C.W. Sutrisno*, Junko. A. Effendy, Maria D. G. Prathivi \\ Universitas Ciputra, Indonesia \\ *timotius.febry@ ciputra.ac.id
}

\begin{abstract}
Entrepreneurial Orientation (EO) and Total Quality Management (TQM) are often referred to as antecedents of growth, competitive advantage and business performance by previous research. This research is the first investigation in a literature study that attempts to show the relationship between EO and TQM concepts on business performance. In this study, we use a multidimensional model on EO and TQM concepts and test a series of hypotheses related to business performance using student business data surveys in the MSMEs scale of Surabaya, East Java. It is expected that the results of this study can answer prepositional questions, whether the two strategies can help improve the performance of MSME-scale businesses in developing countries.
\end{abstract}

Keywords: Entrepreneurial Orientation, MSMEs, Total Quality Management

\section{INTRODUCTION}

The development of quality in Micro, Small and Medium Enterprises (MSMEs) to date has focused on three things, namely quality planning, quality control, and quality improvement. The development of the principle of quality has been contained in the 19-9000-2001 Indonesian National Standard Series Quality Management System (SNI) certification which focuses on quality management. This is seen as one of the company's strategies chosen to answer consumer demands for more critical quality.

Many confirmed company strategies have a strong impact on achieving good business performance. More specifically, some innovative practices and strategies such as total quality management (TQM) that focus on integrated quality can contribute to organizational performance (Al-Dhaafri et al, 2013). Entrepreneurial orientation (EO) focusing on creating and developing an entrepreneurial culture has been widely well said in research articles that have a strong impact on improving organizational performance. However, the results regarding the impact of these practices cannot be summed up thoroughly in the management literature.

A lot of publisher journal said that TQM has a strong effect for business performance (Wiklund and Shepherd, 2005; Kraus et al, 2012; Al-Dhaafri, 2013; Christian, 2018) But some other research confirmed some findings that not all TQMs are successful (Samson and Terziovski, 1999; Sohal and Terziovki, 2000). This difference makes the theoretical gap that must be explored more and deeply in some developing countries, where the issue of quality is still the main obstacle. departing from this, the objective of this study is to investigate the relationship between entrepreneurial presentation and TQM concepts and their effect on business performance on a micro-scale in Surabaya, 
which Surabaya is one of the metropolitan cities in the Republic of Indonesia.

\section{Resource Base View}

The resource-based view (RBV) has been considered as one of the main parts of the research concept that has developed rapidly in recent years. This theory was first introduced to society by Wernerfelt (1984). He argues that organizational succeeds is determined by the organization's internal resources. Resources in this organization could be physical or non-physical assets (Collis, 1994), or competencies such as well knowledge and skills (Teece et al, 1997). The RBV emphasizes the compatibility between the opportunities available and the potential of the organization. Therefore, the main thing for RBV is to consider the full utilization of available internal resources to build core organizational competencies that aim to achieve and maintain a strong organizational value proposition (Makadok, 2001).

This condition becomes difficult for organizations to achieve the same competitive level if the organization considers internal resources such as human capabilities, access to information sources and internal organizational strategies (Barney, 1991). Therefore, organizations must build good relations between the external and internal environment to achieve sustainable competitive advantage. By the implications of the RBV on organizational competitive advantage, RBV on the priority of resources in starting and maintaining the competitive advantage of the organization, therefore this concept must improve relations to choose resources and great potential value for organizations (Makadok, 2001).

\section{TQM and Business Performance in MSMEs}

Most of these studies have confirmed that the adoption of one strategy such as TQM will ultimately add value proposition or competitive advantages to all types of organizations (Sila and Ebrahimpour, 2002). Therefore, some other researches show that TQM has a strong positive relationship with performance results, such as financial performance and profitability (Cummings and Worley, 1997), and other outcomes such as customers' and employees' satisfaction. Employees relation between one another can be maintained too (Lawler et al., 1995) which finally it can increase the company's competitive advantage on any scale.

The use of TQM on organizational performance as an organizational strategy in MSMEs has been studied by several researchers (Feng, 2006; Lee, 2004). The impact of TQM implementation on organizational's main value is evident in the role of TQM fundamentals to encourage business praxis that will increase productivity, quality, gain customer satisfaction, and reduce costs and gain the satisfaction of employees who run it. In other words, the practice of TQM supports organizations to improve business excellence sustainably (Yong and Wilkonson, 1999; Lee, 2002). This study used measurements TQM implementation for MSMEs developed by Rahman (2001) which consisted of leadership, information, and analysis, strategy and planning, product and service processes, people, customer focus. Based on the literature study that has been built, it is hypothesized that the TQM has a positively and significant influence on business performance of MSME.

\section{EO and Business Performance in MSMEs}

The Context of Entrepreneurship has grown rapidly in today's complex globalwide economy, it is a necessity for all organizations to gain and maintain competitive advantage (Covin and Slevin, 1986; Wiklund and Shepherd, 2003). appertain to the business performance of MSMEs, several studies on entrepreneurship in the media are quite popular and overall show a positive relationship between business performance and EO (Lumpkin and Dess, 2001). Lumpkin and Dess (1996) found the difference between entrepreneurial and EO that the EO process answers the question of how the project is carried out, measured and evaluated, while 
entrepreneurship refers to its contents of entrepreneurial decisions by answering what is need to be done.

Some researchers study the relationship between EO and organizational performance in several types of organizations. Most EO studies focus on three dimensions of EO, namely innovation, activity, and risk-taking (Wiklund and Shepherd, 2005; Lumpkin and Dess, 2001; Davis et al, 2010). They examine the moderating effects of industrial life cycles and aggressiveness has a different impact on organizational performance, where proactivity has a positive relationship with organizational performance, but aggressiveness is weakly related performance. Jogaratnam and Tse (2006) examined organic structures from negative relationships with organizational performance. Thus, the following hypothesis is used for further empirical examination, namely, Entrepreneurship Orientation has a positive and significant effect on Business Performance.

Some definitions in the literature try to explain the meaning of the concept of entrepreneurship such as the creation of innovation, the creation of growth, the creation of companies, value creation and job creation (Morris et al, 2008). Furthermore, the concept of entrepreneurship is a social process that depends on the context that comes from wealth through individuals and teams by gathering shared resources to benefit from the market. From their point of view, Slevin and Covin (1990) regard the concept of entrepreneurship as organizational behavior, and EO as a method, process of practice, decision making, and operating philosophy that top management uses their ability to transform their organizations into business entities.

There are several different definitions for aspects of EO. For example, Zahra and Covin (1995) define EO as a potential tool that inspires business organizations, which can be obtained through innovation, proactivity, and risk-taking. Three dimensions of EO have been introduced by
Miller (1983) and the other two dimensions, namely, aggressiveness and autonomy, have been added later in the literature by Lumpkin and Dess (1996). However, most of the research conducted on EO has used three dimensions: Innovative, proactive and risktaking to measure EO (Wiklund, 1999).

Innovativeness as one part of EO is related to providing support for sustainable renewal, the creative process, and the development and creation of new ideas through experiments in organizations (Lumpkin and Dess, 1996). This is more related to the increase in the probability that an organization will get optimal benefits from first movers or innovators (Wiklund, 1999). Therefore, innovation has become the most important factor used to characterize entrepreneurship, and contribute to the profitability and growth of entrepreneurial organizations (Covin and Milles, 1999; Covin and Wales, 2010). To look further in the context of MSMEs, how much the impact of innovation on business performance is hypothesized as follows: innovativeness influences Business Performance.

Proactiveness was related to the willingness of the organization and its ability to expect new developments as soon as possible to have excellence as the first mover about other competitors (Wiklund, 1999). Lumpkin and Dess (2001) state that proactive is an approach to finding new services and product opportunities and responding quickly to customer demand. To look further in the context of MSMEs, how much is the proactive impact on business performance, based on this it is hypothesized as follows: Proactiveness influences Business Performance.

Risk-taking is the level at which managers or strategic decision-makers of an organization are willing to have resource commitments to opportunities that arise where there is a reasonable likelihood of failure (Miller and Friesen, 1978). Also, this concept has been debated by Caruana et al (2002) that innovation cannot be created without taking risks. Therefore, risk-taking is considered to be the most important factor in 
EO which is usually used to show entrepreneurship (Osman et al, 2011). To see further in the context of MSMEs, how much the impact of risk-taking on business performance is hypothesized as follows: risktaking influence on business performance.

\section{EO and TQM Concept}

EO and TQM are a combination of strategies that are very important for organizations to achieve competitive advantage (Abdullah Kaid Al-Swidi, 2012; Al-dhaafri, Zien, \& Yusoff, 2013). In every initiation of corporate strategy implementation, the organization must be driven by the goal of seizing opportunities and enlarging in the market and having the courage to have risks that might occur (Lumpkin and Dess, 2001). This logically implies that organizations that have an EO will have a large tendency to implement high-quality, innovative and sustainable management strategies. The implementation of the TQM concept will have many obstacles without EO being owned by each member of the organization (Imran et al., 2018). This is supported by previous findings (Abdullah Kaid Al-Swidi, 2012), which states that EO and TQM are two things that cannot be separated to build a sustainable business performance of MSMEs. Based on the literature built, the hypothesis proposed is: EO significantly influence on TQM

Based on the development of in-depth literature, the propositions are formulated and can be proposed as the research model attached to Figure 1, as follows:

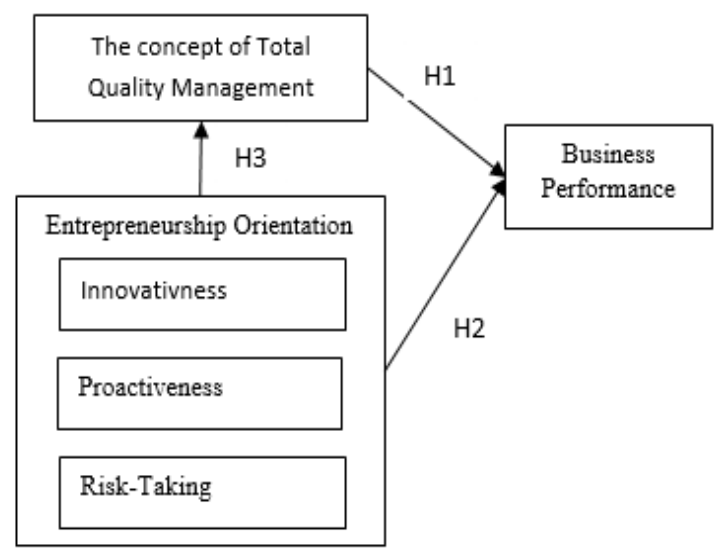

Figure 1. Conceptual Thinking

\section{METHOD}

This study uses a quantitative paradigm. Hypothesis testing uses the Partial Least Square (SEM-PLS) method. While the research analysis unit is students as business people who are conducting business on a micro-scale.

The population in this study were micro-scale business students in the Surabaya area who got entrepreneurial learning. A large population in the regional scope of a city requires an approach used by Ferdinand (2002: 58) stating that the population is the whole of all objects or individuals which each have certain characteristics, clear and complete to study. Complementing Riduwan and Kuncoro (2008: 37) the population is a generalization area consisting of objects, subjects that have a unit of number and certain characteristics set by researchers to be studied and then conclusions drawn. Based on the above theory, consider the principle of population representation. The sampling technique uses purposive random sampling which is one of the non-probability sampling techniques. Selection criteria are chosen by researchers based on the type of business, business age, and domicile.

The measurement scale chosen and used in this study is the Likert scale. The Likert scale is an original scale that is used to measure one's attitudes, opinions and perceptions of social phenomena, where the answers for each instrument item have gradations: 1) strongly disagree (SD), 2) disagree (DS), 3) neutral (N), 4) agree (A), 5) strongly agree (SA). The measurement variables in this study use several indicators as a measure of social phenomena, namely: The concept of TQM consisting of leadership, information, and analysis, strategy and planning, process product and service, people, customer focus. This measurement is developed by Rahman (2001). The EO consists of innovation, proactivity, risk-taking measurement developed by Zahra and Covin (1995). And business performance consisting of financial performance and business growth, developed by Wiklund and Shepherd (2005). 


\section{RESULTS AND DISCUSSION}

The purpose of this study was to look at the influence of the TQM and EO concepts on MSME Business Performance, departing from the perceptive theories of Resource Base View, TQM and EO which are considered as one of the most important resources that can help organizations improve organizational performance (Abdullah Kaid Al-Swidi, 2012; Al-dhaafri, Zien, \& Yusoff, 2013). Based on the phenomenon of inconsistency in some results in previous studies regarding the relationship between TQM and business performance from one side, and EO and business performance from the other, this research needs to be done to strengthen trust in hybrid strategies in supporting business performance on MSME scales especially in developing countries. which is where the contribution of MSMEs greatly supports the country's economic growth.

TQM and EO are seen as qualityoriented strategies that are expected to have an impact on the initial growth of businesses pioneered by beginners. Quality as the main goal in the initial business becomes a common standard in achieving performance. There is a lot of suspicion about whether the MSME business scale requires the TQM concept to help achieve performance, regardless of the local government socialization regarding the minimum quality standards that MSMEs must-have. the next question will be trying to associate with the EO that is owned by each owner in the business, which is the third aspect that is necessary for beginner business people to gain a competitive advantage in the future.

The results of this literature study can be used as a basis for proposing the following propositions:

$\mathrm{H}_{1}$ : TQM influence on business performance.

$\mathrm{H}_{2}$ : Entrepreneurial orientation influence on business performance

H2a:Innovativnes
$\begin{gathered}\text { influence } \\ \text { performance. }\end{gathered}$ on $\begin{array}{r}\text { ownership } \\ \text { business }\end{array}$
$\mathrm{H} 2 \mathrm{~b}$ :Proactiveness influence on business performance.
$\mathrm{H} 2 \mathrm{c}$ :Risk-taking influence on business performance.
$\mathrm{H}_{3}$ : Entrepreneurship orientation influence on TQM concept.

\section{Conclusion}

In this research, many theoretical contributions can be considered for further research. Investigating the influence of the joint relationship of the TQM and EO concepts on business performance is one of the offered in this study. Also, it is hoped that there will be many practical implications from the results of this research that can be developed. The results are expected to help students as MSME business players to improve business performance through the application of the TQM concept with nature and entrepreneurial activities to develop and improve business performance. TQM as a management philosophy sees the application of this philosophy as a fundamental change in the organization that must minimize the risks that will occur and oriented to customer satisfaction. The success of the TQM philosophy can also depend on the culture of entrepreneurship, the availability of information systems, the type of business, leadership that is created, and consistency in business organizations that must be adopted by all members to achieve competitive advantage in the future.

\section{REFERENCES}

Abdullah Kaid Al-Swidi. (2012). Total Quality Management, Entrepreneurial Orientation And Organizational Performance: The Role of Organizational Culture. African Journal of Business Management, 6(13), 4717-4727. https://doi.org/10.5897/AJBM11.2016

Al-Swidi, A. K., \& Mahmood, R. (2013). Total Quality Management, Entrepreneurial Orientation and Organizational Performance: The Role of Organizational Culture. African 
Journal of

Management, 6(13), 4717-4727.

Al-Dhaafri, H. S., Al-Swidi, A. K., \& Yusoff, R. Z. B. (2016). The Mediating Role of Total Quality Management Between The Entrepreneurial Orientation and The Organizational Performance. The TQM Journal, 28(1), 89-111.

Al-Dhaafri, H. S., Yusoff, R. Z. B., \& AlSwidi, A. K. (2013). The Effect of Total Quality Management, Enterprise Resource Planning And The Entrepreneurial Orientation on The Organizational Performance: The Mediating Role of The Organizational Excellence---A Proposed Research Framework. International Journal of Business Administration, 4(1), 66.

Barney, J.B. (1991). Firm Resources And (® Rm Competitive Advantage. Journal of Management, 17, 99-120.

Barney, J. B. (2002). Gaining and Sustaining Competitive Advantage (2nd ed.). Upper Saddle River, NJ: (Prentice Hall).

Caruana, A., Ewing, M.T., \& Ramaseshan, B. (2002). o. The Service Industries Journal, 22(2), 43-58.

Christian F.T., Koesmono Teman., Christiananta Budiman (2018). The Effect of Strategic Leadership and Organizational Culture on The Implementation of TQM and Performance food and beverage company in Indonesia. IJAR. Res. 6(10), 922-929.

Covin, J. G., \& Slevin, D. P. (Eds.). (1986). The Development and Testing of an organizational level Entrepreneurship Scale. Wellesley, MA: Babson College.

Covin, J. G., \& Slevin, D. P. (1991). A Conceptual Mode of Entrepreneurship As Firm Behavior. Entrepreneurship Theory and Practice, (Fall), 7-25.

Collis, D. J. (1994). Research Note: How Valuable are Organizational Competence. Strategic Management Journal, 15,143-152.
Covin, J., \& Miles, M. (1999). Corporate Entrepreneurship and The Pursuit of Competitive Advantage. Baylor University. USA

Covin, J. G., \& Wales, W. J. (2010). The Measurement of Entrepreneurial Orientation. Paper Presented at The Annual Meeting of the Academy of Management (AoM), Montreal, QC.

Cummings, T. G., \& Worley C. G. (1997). Organizational Development and Change. South- Western College Publishing, Ohio. Entrepreneurship: Theory \& Practice, 23(3), 47-63.

Davis, J. L., Bell, R. G., Payne, G. T., \& Kreiser, P. M. (2010). Entrepreneurial Orientation and Firm Performance: The Moderating Role of Managerial Power. American Journal of Business, 25(2), 41-53.

Deming, W. E. (1986). Out of Crisis. Cambridge, MA: Massachusetts Institute of Technology Press.

Demirbag, M., Koh, S. C. L., Tatoglu, E., \& Zaim, S. (2006). TQM and Market Orientation's Impact on SMEs' Performance. Industrial Management \& Data System, 106(8), 1206-1228.

Feigenbaum, A. V. (1983). Total Quality Control. New York: McGraw-Hill.

Feigenbaum, A.V. (1986). Total Quality Control (3rd ed.). New York: McGrawHill

Feng, J., Prajogo, D. I., Tan, K. C., \& Sohal, A. S. (2006). The Impact of TQM Practices on Performance: A Comparative Study Between Australian and Singaporean Organizations. European Journal of Innovation Management, 9(3), 269-278.

Ferdinand, Agusty. 2002. Structural Equation Modelling Dalam Penelitian Manajemen. Semarang: FE UNDIP.

Frank, H., Kessler, A., \& Fink, M. (2010). Entrepreneurial Orientation and Business performance. Schmalenbach Business Review, 62(2), 175-198.

Flynn, B. B., Schroeder, R. G., \& Sakakibara, S. (1995). The Impact of Quality Management Practices on 
Performance and Competitive advantage. Decision sciences, 26(5), 659-691.

GAO. (1991). Report to the House of Representatives on Management Practices: US Companies Improve Performance Through Quality Efforts. United States General Accounting Office, National Security and International Affairs Division, Washington, DC.

Hudson, M., Smart, A., \& Bourne, M. (2001). Theory and Practice in SME pPerformance measurement systems. International journal of operations \& production management, 21(8), 1096-1115.

Imran, M., binti Aziz, A., Binti Abdul Hamid, S. N., Shabbir, M. S., Salman, R., \& Jian, Z. (2018). The Mediating Role of Total Quality Management Between Entrepreneurial Orientation and SMEs Export Performance. Management Science Letters, 519-532. https://doi.org/10.5267/j.msl.2018.5.003

Jogaratnam, G., \& Tse, E.C. (2006). Entrepreneurial Orientation and The structuring of organizations Performance Evidence from the Asian Hotel Industry. International Journal of Contemporary Hospitality Management, 18(6),454-68.

Juran, J. M. (1988). Juran on Planning on Quality. New York: Free Press.

Juran, J.M., \& Gryna, F.M. (1988). Juran's Quality Control Handbook (4th ed.). McGraw-Hill, New York, NY.

Kraus, S., Rigtering, J. C., Hughes, M., \& Hosman, V. (2012). Entrepreneurial Orientation and The Business Performance of SMEs: a Quantitative Study from the Netherlands. Review of Managerial Science, 6(2), 161-182.

Kannan, V. R., \& Tan, K. C. (2005). Just in time, Total Quality Management, and Supply Chain Management: Understanding Their Linkages and Impact on Business Performance. Omega, 33(2), 153-162.
Kementrian Koperasi dan UKM. Laporan Arah Kebijakan Bidang Koperasi Dan Usaha Mikro, Kecil dan Menengah. Maret 2017.

Lawler, E., Ledford, G., Mohman, S., \& Tenkasi (1995). Total Quality Management: Practice and Outcomes in The Largest US firms. Employee Relations, 17(3), 26-41.

Lee, P. (2002). Sustaining Business Excellence Through a Framework of Best Practices in TQM. The TQM Magazine, 14(3), 142-149.

Lee, C. Y. (2004). TQM in Small Manufacturers: an Exploratory Study in China. International Journal of Quality $\&$ Reliability Management, 21(2), 175197

Lumpkin, G. T., \& Dess, G. G. (1996). Clarifying The Entrepreneurial Orientation (EO) construct and Linking it to Performance. Academic of Management Review, 21(1), 135-172.

Makadok, R. (2001). Toward a Synthesis of the Resource-Based and DynamicCapability Views of Rent Creation. Strategic Management Journal, 22(5), 387-401.

Morris, M. H., Kuratko, D. F., \& Covin, J.G. (2008). Corporate Entrepreneurship and Innovation (2nd ed.). Thomson Higher Education, Mason.

Meyer, C. (1994), "How The Right Measures Help Teams Excel", Harvard Business Review, May-June, pp. 95103.

Miller, D., \& Friesen, P. (1978). Archetype of Strategy Formulation. Management Journal, 31, 921-933.

Miller, D. (1983). The Correlates of Entrepreneurship in Three Types of Firms. Management Science, 29, 770791.

Osman, M. H., Rashid, M. A., Ahmed, F. S., \& Hussain, G. (2011). Entrepreneurial Orientation: An Overview of Theory and Insinuations for Women-owned SMBs to Model Business Performance in Developing Countries. Interdisciplinary Journal of 
Contemporary Research in Business, 3(3), 329-340.

Rahman, S. (2001a). A Comparative Study of TQM Practice and Organizational Performance of SMEs with and without ISO 9000 Certification. International Journal of Quality \& Reliability, 18(1), 35-49.

Rahman, S. (2001b). Total Quality Management Practices and Business Outcome: Evidence from Small and Medium Enterprises in Western Australia. Total Quality Management \& Business Excellence, 12(2), 201-210.

Rauch, A., Wiklund, J., Lumpkin, G. T., \& Frese, M. (2009). Entrepreneurial Orientation and Business Performance: An Assessment of Past Research and Suggestions for The Future. Entrepreneurship Theory and Practice, 33(3), 761-787.

Ramlall, S. J. (2002). Measuring Human Resource Management's Effectiveness in Improving Performance. EBSCO Publisher Industries, Inc.

Reed, R., Lemak, D. J., \& Mero, N., P. (2000). Total Quality Management and Sustainable Competitive Advantage. Journal of Quality Management, 5, 526.

Samson, D., \& Terziovski, M. (1999). The Relationship Between Total Quality Management Practices and Operational Performance. Journal of Operations Management, 17(4), 393-409.

Saumyaranjan Sahoo, Sudhir Yadav, (2017) "Entrepreneurial orientation of SMEs, Total Quality Management and Firm Performance", Journal of Manufacturing Technology Management, Vol. 28 Issue: 7, pp.892-912,

Slevin, D.P., \& Covin, J.G. (1990). Juggling Entrepreneurial Style and Organizational Structure-How to Get Your Act Together. Sloan Management Review, Winter, 43-53.

Sink, S. and Tuttle, T. (1989), Planning and Measurement in your Organization of the Future, Industrial Engineering \& Management Press, Norcross, GA.

Teece, D. J., Pisano, G., \& Shuen, A. (1997). Dynamic Capabilities and Strategic Management. Strategic Management Journal, 18, 509-533.

Wiklund, J. (1999). The Sustainability of Entrepreneurial Orientation (EO)Performance Relationship. Entrepreneurship Theory and Practice, 24(1), 37-48.

Wiklund, J., \& Shepherd, D. (2003). Knowledge-Based Resources, Entrepreneurial Orientation, and The Performance of Small and Medium Sized Business. Strategic Management $J, 24(13), 1307-1314$.

Wiklund, J., \& Shepherd, D. (2005). Entrepreneurial Orientation and Small Business Performance: a Configurational Approach. Journal of business venturing, 20(1), 71-91.

Wernerfelt, B. (1984). A Resource-Based View of the Firm. Strategic Management Journal, 5, 171-180.

Yong, J., \& Wilkinson, A. (1999). The State of Total Quality Management: A Review. The International Journal of Human Resource Management, 10(1), 137-161.

Zahra, S. A., \& Covin, J. (1995). Contextual Influences on The Corporate Entrepreneurship-Performance Relationship: A Longitudinal Analysis. Journal of Business Venturing, 10, 4358.

Zahra, S. A. (1999). The Changing Rules of Global Competitive in the 21st Century. Academy of Management Executive, 13(1), 36-42.

Zairi, M. (1994). Leadership in TQM Implementation: Some Case Examples. The TQM Magazine, 6(6), 9-16. 